ordinary chloride of lime. Imperial Chemical Industries, Ltd., has accordingly posted a staff of experts trained in water sterilisation at its divisional offices in London, Newcastle, Manchester, Oldbury and Bristol, whose services will be at the disposal of any local authority desiring them for advice and assistance, which will be given free. Once the proper dosage of the particular chemical agent selected has been determined, together with the best method of applying the process, the routine application is comparatively simple.

\section{Liverpool and the Atlantic Ferry}

A sUMMER meeting of the Institution of Mechanical Engineers in the Liverpool district would not be complete without a paper on ships and their machinery, and during the meeting on June 26-29, Mr. P. Austin, following in the footsteps of the late Mr. A. J. Magennis, contributed a paper on Liverpool and the Atlantic Ferry. Liverpool shipowners have played prominent parts in the long struggle for supremacy on the North Atlantic between such famous lines as the Cunard, White Star, Collins, Inman and others for a century or so. Beginning with the Black Ball line of sailing packets which connected Liverpool and New York in 1816, Mr. Austin traced the development of trans-Atlantic travel down to the present time, mentioning many once famous ships and recalling many great achievements; and in three tables he gave figures of the growth in size, power and speed of typical ships. In concluding his review, Mr. Austin asked, "Is the Liverpool airport to be one of the terminal ports of the Atlantic Ferry of the future?" While not holding that a trans-Atlantic air service is impossible, Mr. Austin has doubts as to its regularity and dependability, due to the vagaries of North Atlantic weather; also there are doubts as to whether such a service ever would be a financial success. As regards the immediate future of the 'Atlantic ferry', the struggle is keener than ever before and the British reply to American, French, German and Italian competition is S.S. No. 534.

\section{The National Maritime Museum}

IN the House of Commons on June 29, Mr. W. Ormsby-Gore, First Commissioner of Works, moved the second reading of the bill for the setting up of a National Maritime Museum in the buildings recently occupied by the Greenwich Hospital School. The cost of adapting the vacant school buildings is estimated at $£ 29,000$ and Sir James Caird has generously offered to defray this sum. Sir James has already given large sums towards the restoration of H.M.SS. Victory and Implacable and presented the Museum with the Macpherson Collection of Naval Prints. There is nowhere, said Mr. Ormsby-Gore, where one can study the history of our maritime adventure and development, and no attempt has yet been made to illustrate conveniently for the general public the immense field of British maritime endeavour, historical, technical, geographical and commercial, including not only the exploits of the
Royal Navy but also of the mercantile marine. A Board of Trustees with the Earl Stanhope as chairman has been appointed and the post of director has been offered to Prof. G. A. R. Callender, of the Royal Naval College, Greenwich, whose enthusiasm and scholarship in all matters appertaining to naval history are well known.

\section{Recent Advances in Physics}

THE Manchester and District Local Section of the Institute of Physics holds each year a summer course of lectures, the primary aim of which is to provide physicists in industry with convenient summaries of recent work in various aspects (both pure and applied) of physical research. This year the lectures were held during June in the Physics Department of the University of Manchester. On June 11, Mr. J. D. Bermal (Cambridge) discussed the properties of "Heavy Hydrogen" and indicated some of its possible chemical uses. Prof. E. N. da C. Andrade (University College, London) dealt with the subject of "Viscosity" on June 13. After considering the relation between temperature and viscosity and its representation by a formula, he discussed a theoretical justification for the use of a formula he has developed and finally dealt with some methods of measurement of viscosities. A comprehensive survey of "Units of Matter" was given by Dr. J. M. Nuttall (University of Manchester) on June 25; he discussed the properties of the proton, electron, anti-proton, positive electron, neutron and neutrino, and gave a summary of the experimental evidence supporting the new ideas on atomic structure. On June 27 short com. munications on "Alloys" were given by Prof. W. L. Bragg, Dr. A. J. Bradley (University of Manchester) and Dr. C. Sykes (Metropolitan-Vickers Electric Co., Ltd.). This is the fourth occasion on which such a course has been held. Last year the meetings were devoted to accounts of the application of physics to particular industries. On this occasion the original plan was adhered to, summaries of recent work in pure science being presented for the convenience of industrial research workers who do not find it easy to follow the many original papers. There has been a gratifying response to the attempt to organise these meetings, and lively discussions have followed most of the papers.

\section{Celtic Earthworks on Salisbury Plain}

Arch felogists are indebted to the Ordnance Survey for further service of no little value in the form of a map of Salisbury Plain, based on the Ordnance Survey map, $1: 25,000$, and showing the Celtic fields and linear earthworks, which is now in course of preparation. The map will be issued in a series of six sections, of which the first, "Old Sarum" (Ordnance Survey, Southampton, 2s. 3d. net), is now ready. The archæological features of the Ordnance Survey map have been taken as a basis, and to these have been added material from photographs of the plain taken by the Royal Air Force in the course of routine duties and from data recorded by members of the staff of the Survey. Dr. J. F. S. Stone, who has 